\title{
Commemorative Celebration in Honor of Ronald Keith Allridge James V. Allridge III
}

$\mathrm{W}$

ith an execution date being set a day before my birthday, 1995

proved to be a very stressing year for me. For those of you who have known me for a while, you know that the hardest thing that I've had to deal with that past year was the execution of my own brother, Ronald Keith Allridge. He was executed by the State of Texas on June 8, 1995.

Ronnie will most likely be remembered by most for the many negative aspects of his life, but not to me. I will remember him as a loving, sensitive, caring, intelligent and quietly reserved person. He loved to read and gather knowledge on all levels. He was a storehouse of erroneous information and would have done well on any quiz show like Jeopardy!

He will be remembered by those remaining on Death Row and those in the abolition movement as one of the first not to willingly walk to his death. He refused to voluntarily come out of the Death Watch Cell and made them come in and physically carry him out. He felt by doing so, he would show them to be exactly what they are - murderers going to get their victim.

The administration proved just how cold-hearted they could be when they asked me to help talk him out of the cell. They attempted to use my desire to see my brother one more time as a bargaining tool to defuse the situation and to quietly lead him to his death. My last words to him were, "Do what you have to do."

I think Beatrice speaks of the disdain of this act best when she wrote to me, "... What they did by [trying] to get you to talk Ronnie out of the cell is the very worst thing they could have done. This is pure torture in my eyes. It is very wrong for them to do. They put Ronnie and you in a dilemma. In a situation that has no solution. You knew that you could see him again if you went, that you wanted to go, but if you went, this would mean that you would help to get him to the execution. Someone who asks this from a brother is the most detestable person in the world .... They are allowed to confine you, to keep you in prison, to take away from you a certain freedom, but they are certainly not allowed to torture you."

Ronnie wrote his "Final Thoughts," what proved to be two days before his death. I would like to publish them, in full, for the first time 
since his murder. I want you all to have a somewhat personal glimpse of the love that he had for those that were involved in his life.

\section{Final Thoughts \\ by Ronald K. Allridge}

As I sit here, about to face my "punishment," I can't help but to wonder what it all means. Will it affect anyone besides me and my family? Will it stop someone else from doing what they are about to do? Will it deter crime? Or, will it just make someone more determined not to be apprehended?

I have been on Texas' Death Row for over nine years now and I have learned quite a few things. One of them is that the violent crime rate in Texas hasn't had a significant decrease in the last ten years, but Texas has executed more people than any other state. Even though Texas has been in the forefront with the amount of executions they've carried out, they are still overwhelmed by crime. Even though they continue to execute people at an alarming rate, they are constantly opening up prisons instead of shutting them down! Why is it so hard for people to understand that, "lockin' 'em up and throwin' away the key" is not the answer? Why can't they realize that capital punishment doesn't deter violent criminal acts? Why do they say they are concerned about the futures of their children when they continue to spend more money on prisons than they do on schools? Haven't they realized that its cheaper to send someone to college than it is to prison? It would definitely be more beneficial to society and the economy to have them with a college degree than a set of parole papers.

I don't know the answer to the world's problems or even all of mine. But I do know that this country is faced with a very dismal future if it continues to journey down this road. It leads nowhere. It didn't lead anywhere in times past and it will lead nowhere in the future. As I said, I don't have an answer to the problems that society faces, but I have solved one problem for myself. That's my fear of dying.

When I was issued my last execution date, I faced that day with an overwhelming dread and a paralysing fear. The mere thought of it terrified me, even though I tried to put up a brave front for my family's sake. Fortunately, I do not have that problem this time. As I face this execution date - assigned to me for June 8, 1995 - I have no fear of what lies 
ahead. I know I do not know what will come after, but I do not fear it. I realize that it is not so much the dying as it is "the fear of." I believe that human beings generally have a fear of death that makes them miss out on a lot of life. They need to conquer that fear before they will ever be able to sincerely feel the most enjoyment out of what they experience in this existence. This is just my opinion, but I believe it to be pretty close to the truth. Anyway, I have conquered that fear now and I have done it just in time. I did it myself, but only because of the help and love given me by the people that mean the most to me. Hopefully, they will hold my memories dear, and cherish their thoughts of me forever.

I want to pay a special tribute to: James Vernon Allridge, Jr., my Dad. He has always been there when I really needed him. Through the good and the bad times he has literally been there, and I know he will continue to be. If I could I would change a few things about our relationship and the way things went growing up, but I would never change the fact that I had someone who was always there. I know whenever I needed someone to turn to, Dad would be there. He might not have done everything right, but he wasn't far from it. He will definitely always be special to me. Thanks Dad, for being you.

Otharee Moss Allridge, my Mom. She really is a special person and means more to me than life. I would have done anything to make her happy because she has always tried her best to do that for me. I have no regrets at all about her being the person that gave me life. That most precious gift has allowed me to experience all the joy, happiness, learning and loving that I have been through over the years and I want to thank her for that more than anything else. We have not always agreed, but we've never argued. And I know the way she feels for me is experienced by only a select few human beings. She has truly made life worth living and I apologize sincerely for any and all hurt or pain that I've caused her. Thank you Mom, for keeping me close to your heart.

$\mathrm{Ah}$, and my daughter. She has truly been a joy to me. I know we have never been with each other in "the world," but my thoughts of her have kept her with me everyday. As I looked into her eyes yesterday and saw the love there that she has for me, this just gave me a feeling that I can't even describe. To know that she could still love me after all the moments she's missed with me just tears my heart. It really makes me wonder what our life would have been like had I been where I was supposed to be. What joys could we have experienced together? What future 
would we have now? I guess these things you don't consider when you are being selfish. Hopefully someone will learn from my experience and realize that, "what you have is more important than what you might get." I just want my daughter, NaDine Michelle Allridge, to know that I have always loved her. She has always had a place in my heart, even before she was who she is now. Daddy loves you Baby!

To my brother, James. I want to thank you for all that you have been. I really have enjoyed and appreciated having your support throughout my life, but especially over the last 10 years. I sincerely wish I could have kept you from this fate, but I was probably too selfish at the time to realize just what I was causing. So, I have tried to make amends by showing you love, devotion and respect, and hopefully this is what you'll remember me for the most. I know I've told you that I love you but those are mere words that I can utter. The true depth of my feelings for you I don't think could ever fully be expressed with mere words. But I want you to know that I do love you, cherish you and will always respect you. I can't imagine a better person to have as a brother and I will always hold your memory dear to me. I don't know what you will experience after I am gone, but I want you to keep your head up, to be strong and always think of me with a smile. Don't be sad for me because I'll be somewhere better. I love you Weinerhead!

To my son, Darius. Even though I wasn't responsible for your birth, I still have always felt as if you were my son. I know I did some things wrong, but I never meant to cause you any harm. Hopefully you can remember me and the times we shared with fondness and decide that I wasn't such a bad person after all. You take care of yourself and your little brother and sister because both of them need you much.

To my brothers: Darren, Lamont, and Stan. I really appreciate all of you keeping me in your hearts. I know I've been away from you more than I've been with you, but you still managed to love me regardless of that fact. It just makes me proud to realize that I have such fine young men as members of my family. Hopefully, our spirits will cross paths again and the next time we'll appreciate it more than we did this time. I wish you to know also that I never meant to cause you any pain, things just worked out that way. I just want you to be strong for each other and always take into account each other's feelings. Its when we forget about others' feelings that things seem to turn out wrong. And remember, "I Will Always Love You." 
I wish to send a special thanks to my "big sister," Peggy. I know she didn't have to let me into her heart, but she did. I hope to meet her one day again so I can let her know just how much she means to me. May you have a bright and beautiful future filled with nothing but wonderful experiences.

I wish to send a special thanks also to my Great Aunt, Robbie Moore. She has provided me with her love and support, and also, a beautiful daughter who is my "big sister." They know that I will always love them and I know they will keep me in their hearts for now and ever.

I wish to thank my attorneys, Don, Bruce, and Steve, for really trying to save my life. They knew it would be an uphill battle all the way but they fought the good fight. Its just too hard for a few people to try and fight a whole state. But knowing they couldn't win didn't stop them from giving their best efforts. To all of them, I wish to say, I sincerely thank you.

I have to thank my "little sisters," Mookie and Ines, for coming into my life and giving me their devotion, trust and love. I really needed them at that particular time, just as I need them now. I hope they continue to have happiness and I want them to know that I will keep them inside of me always.

I wish to send a special thanks to my "wife" because she has meant a lot to me, especially in the last few months. I know we didn't have a formal relationship, but it meant more to me than any I've had. I wish her continued success and happiness in life and I send my love to her and Junaid. I don't know how she'll feel about me leaving her like this but I know it isn't easy for me. Damn, I love you woman and I just know that we will meet again. A love like our's just has to be repeated. I freely love you, Shontia Lahon "Kittit-Kittie" Harris-Allridge!! May you have a bright and beautiful future.

I have countless others that I have on my mind and in my heart. If I were to try and mention them all, I know I wouldn't have enough time left. But I know they will feel me thinking of them and I wish them to think of me. As I embark on this journey, I want only to say that it has been a learning experience. Everything didn't turn out right, but everything didn't turn out wrong either. I hope I have left behind something that will give someone pause or put a smile on their face. 
To everyone that means anything at all to me: MUCH PEACE AND LOVE!

I won't try to paint a perfect picture and say that Ronnie was an angel, filled with love and compassion for his fellow human being. That would be far from the truth - simply, a lie. But he was capable of love and had a great deal of love for many. I miss the love that he showed for me daily.

It is my hope that his death and the many others before him were not in vain. Texas has slacked up on executions, only because of current pending litigation in the courts. I'm sure they would have been executed if the State of Texas and Governor Bush had their way.

June 8, 1997 will be the second anniversary of Ronnie's execution. I am asking that everyone who reads this to light a candle in remembrance of him on this day, or do something to further the abolition of the death penalty. Write a letter to the Governor, help circulate a petition or phone or fax a letter to President Clinton.

Not to diminish the pain and suffering of the victim's family and survivors, but there are always two sides to every story and I know only too well of the pain and suffering of the executed's family. My mother speaks of how she misses Ronnie each time she comes to visit and when she writes. My father tells me how he goes out to the cemetery and just sits and talks to Ronnie when things are troubling his mind. But the thing they don't tell me is how painful it must be for them each time they come to visit me and not see Ronnie there next to me after 8 years of visits. They don't tell me how painful it was for them to have one son executed by the State (with their three youngest sons witnessing the execution) in June of 1995 and then, only a few months later, have the other son come within 5 days of being executed. I have a very strong family and I admire them for their strength and courage.

Ronnie wrote the title poem for my recently released chapbook, Deadly Executioner. He also has several other poems included in the book. The book is dedicated to the numerous men that have been executed by the State of Texas since the reinstatement of the death penalty here in the United States. The book has been received very well so far and I would like everyone to get a copy or two, to pass along to a friend [see: About the Cover, p. 135). 